\title{
下顎運動の前方および後方誘導要素と 臼歯咬合小面の関連性について
}

\author{
九州柬科大学菌科補経学第 1 講座（指導：豊田静夫教授）
}

篠原功

平成元年 6 月 23 日受付

\section{Correlation of Anterior and Posterior Guidance for Mandibular Movement with Occlusal Facet}

Isao Shinohara

\author{
First Department of Prosthetic Dentistry (Director : Prof. Shizuo Toyoda) \\ Kyushu Dental College, Kitakyushu, Japan
}

\begin{abstract}
The occlusal facet of the molar results from functional movement of the teeth and is therefore affected by guidance for the anterior teeth which is anterior guidance for the mandibular movement and by condylar path which is posterior guidance. The facet is expected to have morphology in harmony with these two factors.

With 22 persons with individual normal occlusion as the subjects, observations were made of condylar path, overlap of the anterior teeth region, and characteristic morphology of the occlusal facet of the molar region, and correlation among them was then studied.
\end{abstract}

The results were as follows:

1. The percentages of G.F.O. and C.P.O. were $45.4 \%$ and $54.6 \%$, respectively.

2. Condylar path inclination was $33.6 \pm 5.1^{\circ}$ for G.F.O. and $34.5 \pm 5.5^{\circ}$ for C.P.O. No significant correlation was found between the two.

3. Functional incisal path inclination was $33.4 \pm 10.5^{\circ}$ for G.F.O. and $38.7 \pm 10.0^{\circ}$ for C.P.O. No significant correlation was found between the two.

4. Anatomical incisal path inclination was $33.4 \pm 11.1^{\circ}$ for G.F.O. and $39.3 \pm 9.8^{\circ}$ for C.P.O. Significant difference was found between the two.

5. The inclination of the anterior occlusal facet for the lower first molar was $33.2 \pm$ $7.7^{\circ}$ for G.F.O. and $38.0 \pm 7.3^{\circ}$ for C.P.O. Significant difference was found between the two.

6. Between condylar path inclination and functional incisal path inclination, no significant correlation was found for G.F.O. and C.P.O. Between condylar path inclination and anatomical incisal path inclination, no significant correlation was found for G.F.O. and C.P.O. Between condylar path inclination and inclination of the occlusal facet, no significant correlation was found for G.F.O. or C.P.O.

7. Between functional incisal path inclination and inclination of the occlusal facet, 
significant correlation was found for both G.F.O. and C.P.O.

8. What characterizes G.F.O. and C.P.O. is the difference in the degree between condylar path inclination and incisal path inclination. There was a tendency for C.P.O. to be large in the difference and small for G.F.O.

\section{Key words : Anterior guidance/Posterior guidance/Occlusal facet/ Condylar path inclination}

\section{緒曹}

臼曾の咬合小面は，一般に下顎運動の前方決定要素で ある前歯部の誘導形態と, 後方決定要素である顆路とに 影響され，両者と調和がとれた形態に形成されるはずで ある．有菡疑者においては前方運動時には歯部が，側 方運動時には非作業側の柬がほとんど接触しないこと が，好ましい咬合状態であるとされている1ー10)。この 状態はさらに，側方運動時の作業側の歯の接触状態によ り,グループファンクションドオクルーショョン，カスピ ッドプロテクティッドオクルージョンおよびオルガニッ クオクルージョンなどに分類され，有歯影に対する理想 咬合として推奨されている。

食物咀嚼時においては, 当然上下の菌が接触するが, 天然雬における咬合小面の全てが現在の咬合機能に関与 しているとは限らない．てのととは必ずしも全ての咬合 小面が下頡運動を反映したものではないことを示してお り，咬合小面と調和のとれた顆路と歯牙路についての検 討が数多く試みられている11-21)。

臨床的に顆路を再現するためには，パントグラフ法 22-27)，チェックバイト法28-311などをもとに下影運動 を咬合器上で再現する方法が一般的であるが，そのほか

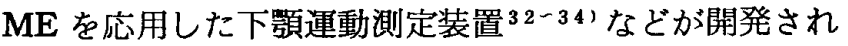
利用されている. 切菌路については，MKG ${ }^{35-371 ， サ ~}$ ホン・ビジトレーナ38! などを利用すれば検討は可能で あるが，乙れらの方法は操作性，経済性などに多くの問 題が伴っており，広く一般臨床家が応用するまでには到 っていない。これらに対して咬合小面は模型だけで形態 的特徴が観察できるので，咬合小面から下頻運動に関す る何等かの情報が得られれば簡便で，しかも広範囲の利 用が期待できる。

そてで，今回著者は，パントグラフ（ディナ一社製） で描記した運動路をもとに，全調節性咬合器（ディナー 社製 D $5 \mathrm{~A}$ ）の関節部を調節して得られた顆路, 前雨部 の誘導形態ならびに前蒾部の被蓋度, さらに釆部咬合 小面の形態的特徴について観察し，乙れらの相互関係に
ついて検討したととろ，興味ある知見が得られたので報 告する。

\section{研 究 方 法}

\section{I ．被験者の選択基準}

被験者は安東 $(1982)^{39}$ ), 久保 $(1984)^{10 !}$, 吳 (1987) 21)の基準に従い，永久歯列が完成し，安定した個性正 常咬合を有するもので，以下の条件を満たするのとし た。

1. 額関節に自覚的にも，臨床診査的にも異常がない とと

2. 雨牙のインターロッキングがなく，速やかに顎運 動ができること

3 . 第 3 大歯以外の欠損がないこと

4 . 修復物があっても少数で, 歯列および歯牙の形態 と機能が損なわれていないてと

5. 開咬, 反対咬合でないてと

6. 矯正の治療経験がないとと

被験者は, 九州霜科大学学生で, 22〜30歳の男女 22 名 とし，その44嚬について検討を加えた。

\section{I . 模型の作製}

本研究は咬合面形態を詳細に検討することが目的であ るので，咬合面の詳細部まで精密に印象，再現できるよ う注意した。そこで，トレー用レジン（而至社製オスト ロン) で個人トレーを作製し，ポリサルファイドラバー 印象材 (而至社製シュールフレックスF) で印象採得し た，印象採得を行う前には，隣接面および咬合面を十分 に清掃した．また，印象採得にあたっては，トレーと印 象材との接着を強力にするため，岸本（1976）４0（の方法 に従って即時重合レジン（而至社製リベロン）をトレー 内面に塗布して，接着剮として利用した。レジンが軟ら かいうちに，咬合面にはインジェクションタイプをシリ ンジで気泡が入らないように注意しながら盛り，トレー にはレギュラータイプを盛って口胿内に挿入し，圧接し た。

模型作製には，超硬石こう（而至社製フジロック）を 
用いた。

II . 下顎運動の記録

A. 前準備

\section{1 . 基準平面の設定}

後方基準点は平均的顆頭点とし，リファレンス・プレ ーン・ロケータ（ディナー社製）を用いて，耳珠上縁と 外眼角を結ぶ直線の下方 $5 \mathrm{~mm}$ の線上で, 外耳道の前方 $12 \mathrm{~mm}$ の点を設定した。

前方基準点は, 打和 $(1986)^{41}$, 蛬 $\left(19872^{211}\right.$ の方法 に従って, 以下のように設定した。 まず, 外耳道下縁点 と鼻翼外側下縁点を結ぶ鼻聴道線を描記し, 後方基準点 より鼻聴道線に下ろした垂線の長さを鼻翼外側下縁点の 上に設定して，てれを前方基準点とした。

とのようにして得られた前方基準点と後方基準点とを 利用して, 補経学的平面と平行な基準平面を設定した (図 1 ).

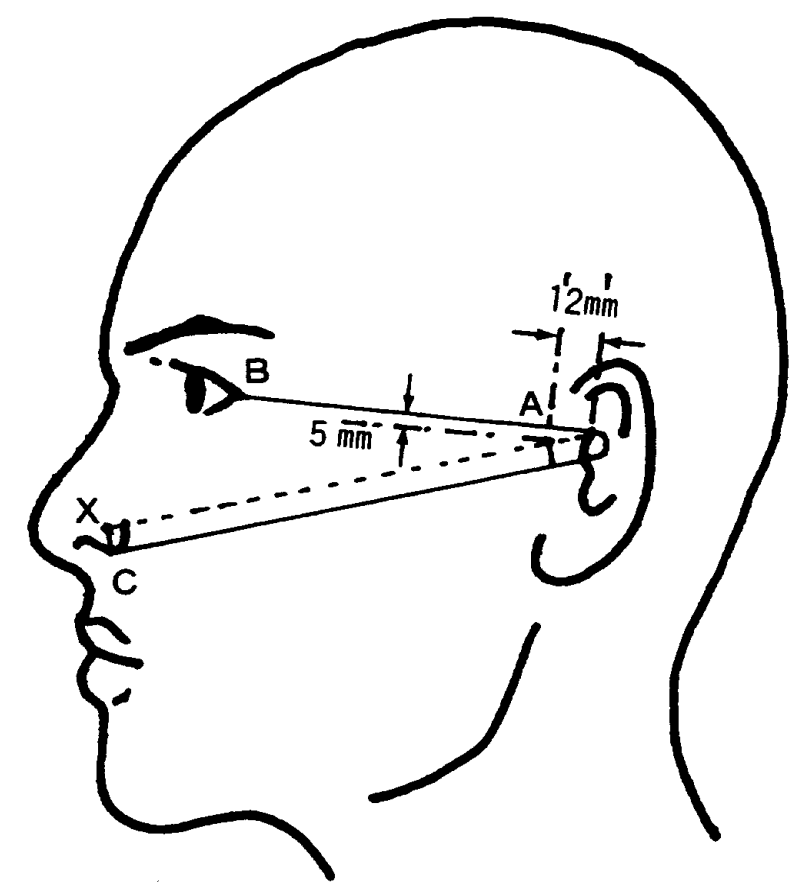

*図 1 基準平面の設定方法
A 平均的顆頭点 (後方基準点)
B 外眼角
C 鼻翼外側下縁点
$\mathrm{X}$ 前方基準点

\section{2. 咬合器への模型付着}

フェイス・ボウ（ディナー社製）により上堮三角を計 測した後，上顎模型を全調節性咬合器（ディナー社製 D 5 A)に付着した。下顎模型は上顎模型に対して中心
咬合位に位置付けて付着した。

3.シーネの作製

歯牙誘導による下顎運動を記録するため，打和 (1986) 41)，呉（1987）212の方法に従って，咬合面を覆わない タィプの上下頜シーネを各被験者に対して作製した。す なわち, プラスティック・クラッチ(ディナー社製) を 加熱軟化して屈曲し，左側第 2 大臼雨汃ら右側第 2 大曰 䨑の煩側面に適合させた，ついで，咬合器上で下影運動 を阻害しないように咬合調整した。さらに，適合性を増 すため，模型上でシーネの内面を即時重合レジン（而至 社製リベロン）を用いて裹装した。

B . 下顎運動の記録および咬合器の調節

各被験者について作製したシーネを口腔内に試適し， 下顎運動時に滑走運動を阻害しないよう調整した後, 荘 科用瞬問接着剤で上下顎の柬に固定した。これにパント グラフ (ディナー社製) を装着して, 中心咬合位を運動 の出発点とした柬牙滑走を伴う下䫁運動を描記した。そ の後, パントグラフ描記路に従って咬合器を調節した。

IV. 咬合形式の分類

咬合器上で中心咬合位から犬歯切端位まで模型を移動 させ，犬雬切端位までの接触点を調べ，安東 $(1982)^{391}$ の分類の改良法により咬合形式を分類した。

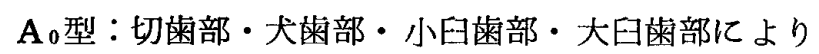
誘導される群

$\mathbf{A}_{1}$ 型：犬米部・小四菌部・大臼崡部により誘導され る群

$\mathrm{B}_{0}$ 型：切歯部・大瞇部・小曰柬部により誘導される 群

$\mathrm{B}_{1}$ 型：犬菡部・小曰曾部により誘導される群

$\mathrm{C}_{0}$ 型：切歯部・犬歯部により誘導される群

$\mathrm{C}_{1}$ 型：犬雬部のみにより誘導される群

V . 咬合器に再現された顆路および匊牙路の計測

A. 顆路について

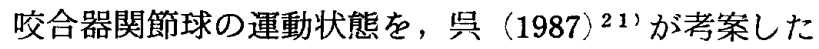
顆路測定装置を使用して計測した。この装置は, 左右関 節球中心点より外方 $15 \mathrm{~mm}$ の点に計測針を取り付けたも のである．との装置を使用して，切端咬合位まで動かし たとき, 咬合器上弓の運動に伴って動く関節中心点より $15 \mathrm{~mm}$ 外方の点の動きを, 三次元読取顕微鏡（ピカ精工 社製 MU-1001) とそれに装着したデジタル・リードア ウト・ユニット（日本光学社製 MC-101）を使用して, $1 / 10 \mathrm{~mm}$ までを有効数字として計測した．とれにより得 られた值より，矢状前方顆路傾斜角（以下顆路傾斜角と 略す)を算出した。 


\section{B . 雨牙路について}

\section{1. 切㐘路について}

インサイザルテーブル上に自硬性レジンを盛り，レジ ンが軟らかいうちに咬合器を運動させて誘導板を調整し た. さらに切雪指導部を形成したインサイザルテーブル 上での計測を正確にするため，中心咬合位および切端咬 合位で自硬性レジンを再び盛ってインサイザルピンを固 定し，インサイザルテーブルの微調整を行った．

インサイザルテーブル上に印記された中心咬合位，切 端咬合位を三次元読取影微鏡で計測し，中心咬合位と切 端咬合位間の金直距離ならび水平距離を求め, $\tan ^{-1}$ （垂直移動距離/水平移動距離）加ら矢状切菌路傾斜角を 求めた．以下これを機能的切柬路傾斜角という.

\section{2 . 前歯の被蓋度について}

上䯪および下顎左側中切曾切縁近心隅角部に，それぞ れ上䫑切爾点, 下頧切霜点を印記した. 咬合器上で中心

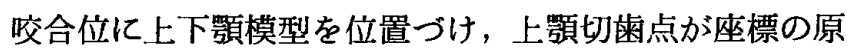
点となるように，3 次元䛃取顕微鏡（ニコン社製）とそ れに連動するリードアウト・ユニットを位置づけた。そ の後, 上䫕模型を咬合器上弓とともに咬合器から取り除 き，下顥切雨点の座標值 $(x, y, z)$ を読み取った。 このとき $\mathrm{x}$ 軸は前頭方向 (左右方向)，y 軸は矢状方向 (前後方向), $\boldsymbol{z}$ 軸は上下方向の座標值とした。

こ机ら上下顎中切夹の水平的被蓋度 $(\mathbf{y})$, 垂直的被 蓋度 $(z)$ より, 切歯路傾斜角 $\left(\tan ^{-1} z / y\right)$ を求め た. 以下とれを解剖学的切歯路傾斜角という。

3. 咬合小面について

左右側下顎第 1 大曰曾の前方咬合小面の外形を $3 \mathrm{H}$, $0.3 \mathrm{~mm}$ のペンシルで注意深く描記し，フォームコーダ

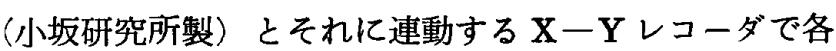
咬合小面の形態を，清水 $(1987)^{42}$ の方法にしたがって 記録した。すなわち，模型をフォ一ムコーダの専用載物 台にのせ，スタイラスの走行方向と模型の正中方向が一 致するように調整した。

その後, 左右側下頻第 1 大臼霜の各前方咬合小面につ いて0.5mm幅でフォームコーダのスタイラスを走らせ， 各咬合小面の煩舌範囲の全ての矢状断面形態を基準平面 である咬合平面の方向とともに X-Yレコーダに描記し た。

描記された前方咬合小面を図 2 亿示す．曲線AB B A 部付近は中心咬合位あたりでの罡運動に関与してお り，滑走運動には関与していない部分であると判断し， この部は対象としなかった，咬合小面の形態的特徽は， 下頼がある程度偏心滑走運動して機能すると思われる位
置で比較検討すべきであるので，直線部分を延長し，て れが基準平面である咬合平面とのなす角度 $\angle \mathrm{BCO}$ を分 度器で計測して, 前方咬合小面の矢状面傾斜角 (以下咬 合小面傾斜角と略す）とした。

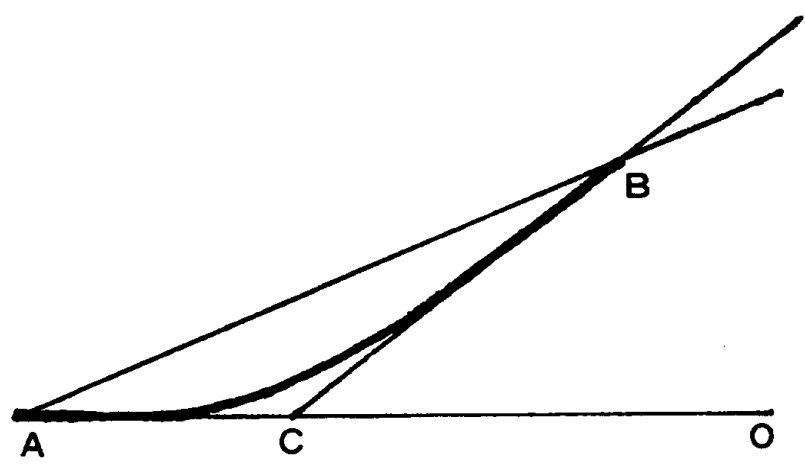

図2 前方咬合小面矢状断面形態

VI . 検討項目

得られた計測結果から，以下の各項目について相関性 の検討を行った.

1. 顆路傾斜角之解剖学的切畨路傾斜角の相関性

2. 顆路傾斜角之機能的切曾路㑯斜角之の相関性

3 . 顆路傾斜角之咬合小面傾斜角之の相関性

4. 機能的切歯路傾斜角と咬合小面傾斜角との相関性

\section{研 究 結 果}

I . 咬合形式の分類

被験者22名の44頻に関して，側方運動時に接触する上 下㖽歯牙を咬合器上および口腔内で観察し，その結果を 表 1 に示した。

側方運動時の誘導菌が切蒾部，犬霜部，小画部，大 曰雨部であるグループファンクションドオクルージョン ( $\mathrm{A}_{0}, \mathrm{~A}_{1}$ 群. 以下 G.F.O. と略す) の割合は $45.4 \%$ ， 側方運動時の誘導歯が犬菌部のみ, 犬雨部・小自菌部, および切柬部・犬苗部・小苗菌部であるカスピッドプロ テクティッドオクルージョン $\left(\mathrm{B}_{0}, \mathrm{~B}_{1}, \mathrm{C}_{0}, \mathrm{C}_{1}\right.$ 群. 以下 C.P.O. と略す) の割合は $54.6 \%$ あったた。

表 1 咬合形式の分類

\begin{tabular}{|c|c|c|c|c|}
\hline & \multicolumn{3}{|c|}{ 咬 合 形 式 } & \multirow{2}{*}{ total } \\
\hline & A & B & C & \\
\hline I & 13.6 & 22.7 & 4.6 & 40.9 \\
\hline $\mathrm{N}-\mathrm{I}$ & 31.8 & 18.2 & 9.1 & 59.1 \\
\hline total & 45.4 & 40.9 & 13.7 & 100.0 \\
\hline
\end{tabular}


側方運動の誘導に切雬群が関与していた $\left(\mathbf{A}_{\mathbf{0}}, \mathbf{B}_{\mathbf{0}}\right.$, $\mathrm{C}_{0}$ 群. 以下 I 群と略す) 割合は $40.9 \%$ ，切歯群が関与 していない（ $\mathrm{A}_{1}, \mathrm{~B}_{1}, \mathrm{C}_{1}$. 以下 $\mathrm{N}$ - I 群と略す）割合 は59.1\%であった。

I . 咬合器に再現された顆路および菌牙路について

A. 顆路傾斜角について

顆路傾斜角に関する計測結果を表 2 に示した。

全ての被験者の顆路傾斜角の平均值と標準偏差は34.1 士5.3度であり，G.F.O. 群と C.P.O. 群では，それぞ

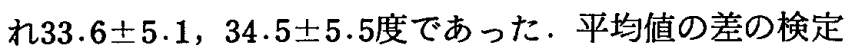
を行ったところ, 両者間に有意の差は認められなかった (表 3 ).

表 2 顆路傾斜角

\begin{tabular}{l|cc|c}
\hline \hline & G.F.O. & C.P.O. & 平 均 \\
\hline $\mathrm{I}$ & $28.6 \pm 3.5$ & $33.0 \pm 6.4$ & $31.6 \pm 5.9$ \\
$\mathrm{~N}-\mathrm{I}$ & $35.7 \pm 4.1$ & $36.0 \pm 4.2$ & $35.9 \pm 4.0$ \\
\hline 平 均 & $33.6 \pm 5.1$ & $34.5 \pm 5.5$ & $34.1 \pm 5.3$ \\
\hline
\end{tabular}

(単位 度)

表 3 顆路, 菊牙路に関する G.F.O., C.P.O. 間 の差の検定

\begin{tabular}{|c|c|c|c|}
\hline & G.F.O. & C.P.O. & $\begin{array}{l}\text { 平均値の } \\
\text { 差の検定 }\end{array}$ \\
\hline 顆 路 傾 斜 角 & $33.6 \pm 5.1$ & $34.5 \pm 5.5$ & - \\
\hline $\begin{array}{c}\text { 機能的切眯路 } \\
\text { 傾斜角 }\end{array}$ & $33.4 \pm 10.5$ & $38.7 \pm 10.0$ & - \\
\hline $\begin{array}{r}\text { 解剖学的切茵路 } \\
\text { 傾斜角 }\end{array}$ & $33.4 \pm 11.1$ & $39.3 \pm 9.8$ & * \\
\hline 咬合小面㑯斜角 & $33.2 \pm 7.7$ & $38.0 \pm 7.3$ & * \\
\hline \multicolumn{4}{|c|}{ (単位 度) } \\
\hline
\end{tabular}

表 4 顆路, 歯牙路に関する I 群, N-I 群間の差 の検定

\begin{tabular}{|c|c|c|c|}
\hline & I & $\mathbf{N}-\mathbf{I}$ & $\begin{array}{l}\text { 平均値の } \\
\text { 差の検定 }\end{array}$ \\
\hline 顆 路 傾 斜 角 & $31.6 \pm 5.9$ & $35.9 \pm 4.0$ & 一 \\
\hline $\begin{array}{l}\text { 機能的切歯路 } \\
\text { 傾斜角 }\end{array}$ & $36.3 \pm 10.5$ & $36.4 \pm 10.7$ & - \\
\hline $\begin{array}{r}\text { 解剖学的切眯路 } \\
\text { 傾斜角 }\end{array}$ & $38.0 \pm 10.6$ & $35.7 \pm 10.8$ & - \\
\hline 咬合小面傾斜角 & $35.7 \pm 8.4$ & $35.8 \pm 7.6$ & - \\
\hline
\end{tabular}

(単位 度)

一 有意差なし

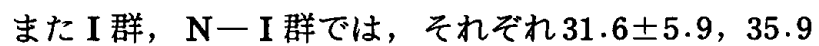
土4.0度であり, 両者間に有意の差は認められなかった (表 4 ).

B . 歯牙路について

1. 機能的切歯路傾斜角について

機能的切歯路傾斜角に関する結果を咬合形式別に分類 して表 5 に示した.

全ての被験者の機能的切曾路傾斜角の平均値と標準偏 差は36.4 10.5度であった。

G.F.O. 群と C.P.O. 群では，それぞれ33.4士10.5， $38.7 \pm 10.0$ 度であり, 平均值では C.P.O. の方が大で あったが，両者間に有意差は認められなかった（表 3 ）。

I 群，N-I 群ではそれぞれ $36.3 \pm 10.5 ， 36.4 \pm 10.7$ 度であり，両者間に有意の差は認められなかった（表 4).

I 群では G.F.O.と C.P.O. で差はほとんどなかっ たが，N－I群では C.P.O. が G.F.O.より有意差を もって大であった（表 5 ).

2 . 解剖学的切歯路傾斜角について

解剖学的切菌路傾斜角に関する計測結果を咬合形式別 に分類して表 6 に示した。

全ての被験者の解剖学的切凷路傾斜角の平均值と標準 偏差は36.6士10.7度であった。

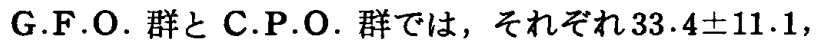

表 5 機能的切茵路㑯斜角

\begin{tabular}{|c|c|c|c|c|}
\hline & G.F.O. & C.P.O. & 平均 & $\begin{array}{l}\text { 平均值の } \\
\text { 差の検定 }\end{array}$ \\
\hline I & $38.5 \pm 14$ & $35.3 \pm 8.2$ & $36.3 \pm 10.5$ & 一 \\
\hline $\mathbf{N}-\mathbf{I}$ & $31.0 \pm 7$ & $42.2 \pm 10.9$ & $36.4 \pm 10.7$ & * \\
\hline 平均 & $33.4 \pm 10$ & $38.7 \pm 10.0$ & $36.4 \pm 10.5$ & \\
\hline & & $\begin{array}{c}\text { (単位 } \\
-\quad \text { 有 } \\
* \text { 危 }\end{array}$ & $\begin{array}{l}\text { 度) } \\
\text { 差なし } \\
\text { 率 } 5 \% \text { }\end{array}$ & Eあり \\
\hline
\end{tabular}

表 6 解剖学的切菌路傾斜角

\begin{tabular}{l|cc|c|c}
\hline \hline & G.F.O. & C.P.O. & 平 均 & $\begin{array}{c}\text { 平均值の } \\
\text { 差の検定 }\end{array}$ \\
\hline $\mathrm{I}$ & $38.2 \pm 14.9$ & $37.9 \pm 8.5$ & $38.0 \pm 10.6$ & - \\
$\mathrm{N}-\mathrm{I}$ & $31.4 \pm 8.9$ & $40.8 \pm 11.0$ & $35.7 \pm 10.8$ & $*$ \\
\hline 平均 & $33.4 \pm 11.1$ & $39.3 \pm 9.8$ & $36.6 \pm 10.7$ & \\
\hline
\end{tabular}

(単位 度)

一 有意差なし

* 危険率 $5 \%$ で有意差あり 
$39.3 \pm 9.8$ 度であり, 平均值に関して両者間に有意の差 が認められた（表 3 ).

I 群，N-I群ではそれぞれ $38.0 \pm 10.6,35.7 \pm 10.8$ 度であり，両者間に有意の差は認められなかった（表 $4)$.

I 群では G.F.O.と C.P.O. で差はほとんどなかっ たが，N-I 群では C.P.O.が G.F.O.より有意差を もって大であった（表 6).

3 . 咬合小面傾斜角について

下顎第 1 大曰歯における前方咬合小面傾斜角に関する 計測結果を，咬合形式別に分類して表 7 に示した。

全ての被験者の咬合小面傾斜角の平均値之標準偏差は $35.8 \pm 7.8$ 度であった。

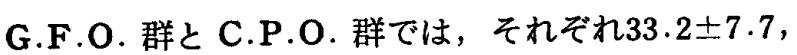
$38.0 \pm 7.3$ 度であり, 両者間に有意の差が認められた (表 3 ).

I 群， N-I 群では，それぞれ35.7 $\pm 8.4,35.8 \pm 7.6$ 度であり，両者間に有意の差は認められなかった（表 $4)$.

I群ではG.F.O.とC.P.O. で差はほとんどなかっ たが，N-I群では C.P.O.がG.F.O.より有意差を もって大であった（表 7 ).

表 7 咬合小面傾斜角

\begin{tabular}{|c|c|c|c|c|}
\hline & G.F.O. & C.P.O. & 平 均 & \begin{tabular}{|} 
平均値の \\
差の検定
\end{tabular} \\
\hline I & $35.9 \pm 11.5$ & $35.7 \pm 7.0$ & $35.7 \pm 8.4$ & - \\
\hline $\mathrm{N}-\mathrm{I}$ & $32.0 \pm 5.6$ & $40.2 \pm 7.3$ & $35.8 \pm 7.6$ & * \\
\hline 平均 & $33.2 \pm 7.7$ & $38.0 \pm 7.3$ & $35.8 \pm 7.8$ & \\
\hline
\end{tabular}

I. 顆路㑯斜角, 切歯路傾斜角, 咬合小面㑯斜角の相互 関係について
A. 顆路傾斜角
（C）之機能的切䨑路傾斜角
(L) との
関係について

顆路㑯斜角之機能的切菌路傾斜角とを比較するため に, 個々の計測値の顆路傾斜角から機能的切歯路傾斜角 を引いた值で比較したところ，G.F.O. 群ではー0.3士 13.8度であり平均值ではほとんど差がなく，C.P.O. 群

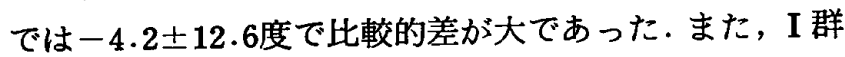
では-4.8 15.1度で平均值では差が大であり, N-I 群

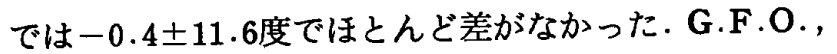
C.P.O., I， N-I 群のすべてで約60〜70\%の被験者
において顆路傾斜角よりも機能的切歯路傾斜角の方が大 であった（表 8 ).

顆路傾斜角と機能的切歯路㑯斜角の相関関係を求めた ととろ，全ての被験者を対象にした場合にはー0.41であ った. G.F.O. 群, C.P.O. 群では, 両者とも有意の相 関関係は認められなかった。I 群，N-I 群では, 前者 では有意の相関関係が認められたが，後者では認められ なかった（表 9 〜2).

表 8 顆路傾斜角 $(\mathrm{C})$ と機能的切歯路傾斜角 (L) と の差

\begin{tabular}{l|c|c|c}
\hline \hline & $\mathrm{C}-\mathrm{L}_{(\text {(⿸广⿱廿又) }}$ & $\mathrm{C}>\mathrm{L}_{(\%)}$ & $\mathrm{C}<\mathrm{L}_{(\%)}$ \\
\hline G.F.O. & $-0.3 \pm 13.8$ & 37.4 & 62.6 \\
C.P.O. & $-4.2 \pm 12.6$ & 33.3 & 66.7 \\
\hline I & $-4.8 \pm 15.1$ & 33.3 & 66.7 \\
N-I & $-0.4 \pm 11.6$ & 38.0 & 62.0 \\
\hline
\end{tabular}

表 9 G.F.O. 群における顆路と苗牙路の相関関係

\begin{tabular}{|c|c|c|}
\hline $\begin{array}{l}\text { 機能的切雪路 } \\
\text { 傾斜角 }\end{array}$ & -0.49 & \\
\hline 解剖学的切歯路 & -0.57 & \\
\hline 咬合小面傾斜角 & -0.35 & $0.95^{*}$ \\
\hline & 顆 路 傾 斜 角 & $\begin{array}{c}\text { 機能的切疄路 } \\
\text { 斜角 }\end{array}$ \\
\hline
\end{tabular}

表10 C.P.O. 群における顆路と粜牙路の相関関係

\begin{tabular}{|c|c|c|}
\hline 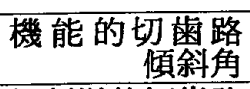 & -0.30 & \\
\hline $\begin{array}{r}\text { 解剖学的切菌路 } \\
\text { 傾斜角 }\end{array}$ & -0.35 & \\
\hline 咬合小面傾斜角 & -0.07 & $0.83^{*}$ \\
\hline & 顆 路 傾斜 角 & $\begin{array}{c}\text { 機能的切霓路 } \\
\text { 路斜角 }\end{array}$ \\
\hline
\end{tabular}

* 危険率 $5 \%$ で有意

表11 I 群における顆路と㐘牙路の相関関係

\begin{tabular}{|c|c|c|}
\hline $\begin{array}{c}\text { 機能的切電路 } \\
\text { 傾斜角 }\end{array}$ & $-0.68^{*}$ & \\
\hline 解剖学的切菡路 & $-0.68^{*}$ & \\
\hline 咬合小面傾斜角 & -0.54 & $0.95^{*}$ \\
\hline & 顆 路 傾 斜 角 & $\begin{array}{c}\text { 機能的切雬路 } \\
\text { 倾斜角 }\end{array}$ \\
\hline
\end{tabular}

* 危険率 $5 \%$ で有意 
表12 N-I 群における顆路と菌牙路の相関関係

\begin{tabular}{|c|c|c|}
\hline \multirow{2}{*}{$\begin{array}{r}\text { 機能的切霜路 } \\
\text { 傾斜角 } \\
\text { 解剖学的切畨路 } \\
\text { 傾斜角 }\end{array}$} & -0.11 & \\
\hline & -0.15 & \\
\hline 咬合小面傾斜角 & 0.16 & $0.84^{*}$ \\
\hline & 顆 路 傾 斜角 & $\begin{array}{r}\text { 機能的切再路 } \\
\text { 傾斜角 }\end{array}$ \\
\hline
\end{tabular}

* 危険率 $5 \%$ で有意

\section{B . 顆路傾斜角 (C) と解剖学的切歯路傾斜角 ( $\mathrm{L}^{\prime}$ ) そついて}

顆路傾斜角と解剖学的切歯路傾斜角とを比較するため に, 個々の計測値の顆路傾斜角から解剖学的切菡路傾斜 角を引いた值で比較したところ， G.F.O. 群では -0.2 \pm 14.6 度で平均值ではほとんど差はなく，C.P.O. 群で は $-4.8 \pm 12.8$ 度で差が大であった。また，I群では

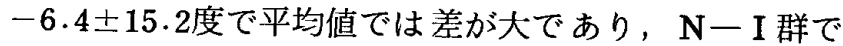

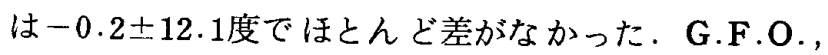
C.P.O., I， N-I 群のすべてで約60～70\%の被験者 において顆路傾斜角よりも解剖学的切菌路傾斜角の方が 大であった（表13）。

表13 顆路傾斜角 (C) と解剖学的切菡路傾斜角 ( L') との差

\begin{tabular}{l|c|c|c}
\hline & $\mathrm{C}-\mathrm{L}^{\prime}{ }_{(\text {度 })}$ & $\mathrm{C}>\mathrm{L}^{\prime}{ }_{(\%)}$ & $\mathrm{C}<\mathrm{L}^{\prime}{ }_{(\%)}$ \\
\hline G.F.O. & $-0.2 \pm 14.6$ & 30.0 & 60.0 \\
C.P.O. & $-4.8 \pm 12.8$ & 38.3 & 61.7 \\
\hline I & $-6.4 \pm 15.2$ & 33.3 & 66.7 \\
N-I & $-0.2 \pm 12.1$ & 31.3 & 68.7 \\
\hline
\end{tabular}

顆路傾斜角々解剖学的切菌路傾斜角の相関関係を求め たところ，全ての被験者を対象にした場合にはー0.33で あった.G.F.O. 群, C.P.O. 群の両者で有意の相関関 係は認められなかった。I 群では有意の相関関係が認め られたが， N-I 群では有意の相関関係は認められなか った（表 $9 \sim 12$ ).

C . 顆路傾斜角 (C) と咬合小面傾斜角 (M) との相関 関係について

顆路傾斜角之下䫇第 1 大曰蒾の前方咬合小面咬頭傾斜 角とを比較するために，個々の計測値の顆路傾斜角から 咬合小面傾斜角を引いた值を求めたところ， G.F.O. 群では $-0.4 \pm 10.6$ で平均值ではほとんど差はなく,

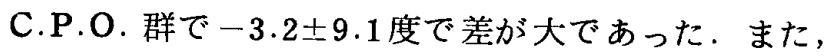

I 群では $-4.2 \pm 12.6$ 度で平均值では差が大であり， N-I 群では $-0.4 \pm 7.8$ 度でほとんぞ差はなかった。 G.F.O., C.P.O., I , N-I 群のすべてで約 60〜80 $\%$ の被験者において顆路傾斜角よりも咬合小面傾斜角の 方が大であった（表14）.

顆路傾斜角と咬合小面傾斜角との相関係数を求めたと ころ, 全ての被験者を対象にした場合には一0.16であっ た.G.F.O. 群，C.P.O. 群とも有意の相関関係が認め られず，また I 群， N-I 群でも有意の相関関係が認め られなかった（表 $9 〜 12$ ).

D. 機能的切歯路傾斜角 (L) と咬合小面傾斜角 (M) との相関関係について

機能的切菌路傾斜角之下額第 1 大曰歯前方咬合小面傾 斜角とを比較するために，個々の計測值の機能的切䨑路 傾斜角から咬合小面傾斜角を引いた值を求めたところ， G.F.O. 群と C.P.O. 群ではそれぞれ $-0.1 \pm 3.9,0.8$ 士5.7度であった。I I 群と N一I 群ではそれぞれ $0.8 \pm$ 3.2,0.2 45.8 度であった. G.F.O., C.P.O., I, $\mathrm{N}$-I 群のすべてで約50〜65\%の被験者において機能的 切歯路傾斜角上りも咬合小面䝨斜角の方が大であった (表15) .

機能的切歯路傾斜角之咬合小面傾斜角の相関係数を求 めたところ，全ての被験者を対象にした場合には0.89で あった.G.F.O. 群, C.P.O. 群では，それぞれ0.95， 0.83 であり，両者とも有意の相関関係が認められた。I 群，N-I群では，それぞれ0.95，0.84であり，両者と も有意の相関関係が認められた（表 $9 \sim 12$ ).

表14 顆路傾斜角 (C) と咬合小面傾斜角 $(\mathbf{M})$ との差

\begin{tabular}{l|c|c|c}
\hline & $\mathrm{C}-\mathrm{M}_{(\text {度 })}$ & $\mathrm{C}>\mathrm{M}_{(\%)}$ & $\mathrm{C}<\mathrm{M}_{(\%)}$ \\
\hline G.F.O. & $-0.4 \pm 10.6$ & 30.0 & 70.0 \\
C.P.O. & $-3.2 \pm 9.1$ & 22.3 & 77.3 \\
\hline I & $-4.2 \pm 12.6$ & 22.2 & 77.7 \\
N-I & $-0.4 \pm 7.8$ & 36.2 & 63.8 \\
\hline
\end{tabular}

表15 顆路傾斜角 $(\mathbf{L})$ と咬合小面傾斜角 $(\mathbf{M})$ との差

\begin{tabular}{l|r|l|l} 
& $\mathrm{L}-\mathrm{M}_{(\text {度 })}$ & $\mathrm{L}>\mathrm{M}_{(\%)}$ & $\mathrm{L}<\mathrm{M}_{(\%)}$ \\
\hline G.F.O. & $-0.1 \pm 3.9$ & 42.1 & 57.9 \\
C.P.O. & $0.8 \pm 5.7$ & 37.5 & 62.5 \\
\hline I & $0.8 \pm 3.2$ & 50.0 & 50.0 \\
N-I & $0.2 \pm 5.8$ & 36.0 & 64.0 \\
\hline
\end{tabular}




\section{考察}

曰斗の咬合小面は，上下菌牙の滑走運動によって生じ たものであるため, 下顎運動の前方決定要素である前菌 部の誘導形態と, 後方決定要素である顆路とに影響さ れ，両者とも調和がとれた形態をしているはずである. この調和を保つ方法として Bonwill (1899) ${ }^{43)}$, Gysi $(1929)^{44}$ ，矢崎 $(1929)^{45}$ らは, 天然崡列においても フルバランスドオクルージョンを付与すべきであること を提唱した。しかし，この咬合形式を天然歯列に対して 付与することは好ましくないことが経験的に明らかとな り, D'Amico (1961) ${ }^{46)}$, Alexander $(1963)^{47)}$ らに より提唱されたカスピッドプロテクティッドオクルージ ョン，あるいは Shore $(1952)^{48)}$, Schuyler (1959) 49), Ramf jord ら（1966）50) らにより提唱されたグル 一プファンクションドオクルージョンが有柬䫟に対する 理想咬合であるとされている。

このような咬合関係を決定するのは咬合小面の接触状 態であり，咬合小面の果たす役割は極めて大きい。しか し, 咬合小面の中には現在の咬合状態を表現しているも のもあるし，現在は接触していないものも含まれる.す なわち, 食物咀嚼時には上下の曾牙は接触することは当 然であるが, 咬合小面の全てが現在の咬合機能に関与し ているとは限らない，てのことは必ずしも全ての咬合小 面が下顎運動を反映したものではないことを示してい る、それにもかかわらず，咬合小面は模型だけで形態的 特徴が観察でき, 咬合小面から下顎運動に関する何等か の情報が得られれば好都合であるため, 調和のとれた顆 路と菌牙路との関係を咬合小面の立場から検討するとと が試みられている11-211。

著者は，パントグラフ法で描記した運動路をもとに， 全調節性咬合器の関節部を調節して得られた顆路と, 前 歯部の誘導形態ならびに前曾 部の被蓋度との観察を行 い,さらに自部咬合小面の形態的特徴についても観察 し，これらの相互関係について検討した.

I . 咬合形式の分類について

被験者 22 名の44頢に関して, 側方運動時に接触する歯 牙を咬合器上および口腔内で観察したところ, 犬柬だけ が側方運動を誘導する例 $\left(\mathrm{C}_{1}\right)$ は $9.1 \%$ と非常に少数で あり，犬蒾と小曰柬が誘導茵の例 $\left(\mathrm{B}_{1}\right)$ は $18.2 \%$ あ った。

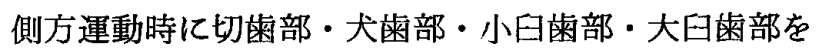
誘導蒾とする群をグループファンクションドオクルージ ョン（G.F.O.），てれ以外のものをカスピッドプロテク
ティッドオクルージョン (C.P.O.) として分類したと ころ，その頻度はそれぞれ45.4，54.6\%であった。この 方法で分類した安東 $(1982)^{39}$ は G.F.O. が $42.4 \%$, C.P.O. が57.6\%，点 $(1987)^{21)}$ はそれぞれ $48.3,51.7$ \%と報告しており，彼らが報告した結果とほとんど同様 の傾向であることが確認された。

また，側方運動の誘導に切曾群が関与していた群と， 関与していない群との比率はそれぞれ40.9，59.1\%であ り，切䍘部が関与しない例の方がわずかに多いととが確 認された. 安東 $(1982)^{39 \prime}$ はそれぞれ48.9，51.1\%，ま た烟ら（1979（18)は34.5，65.5\%と報告しており，著者 の計測值はこれらのほぼ中間值であった。

\section{I. 顆路について}

前方決定要素の霜牙路とともに，顆路は下䅡運動の後 方決定要素として，下筫運動に対して重要な誘導要因で ある、顆路を臨床的に測定するには，チェックバイト 法, パントグラフ法およびエレクトリックパントグラフ 法などが利用できる，本研究では，臨床的に使用する上 で簡便であること, かなりの精度が得られること, 顆路 と柬牙路とが同時的に観察できることを考慮して，パン トグラフ法を採用するととにした．

パントグラフ法で顆路を測定する場合には，雪牙誘導 と非米牙誘導とでは計測される顆路が変化する可能性が あることを鶴見 $(1975)^{25}$ が指摘している．また，打和 $(1986)^{41}$ ' は顎運動描記時に咬合高经を挙上し過ぎると 顆路に影響が生じることを指摘している．本研究では顆 路と䨑牙路との相関性について検討することが目的であ る.そこでこれらの報告を参考にして，咬合高径を挙上 せず，粜牙誘導時の顆路を計測するために，咬合面を 被覆しないタイプのシーネを自作して，パントグラフ描 記を行った。その後, 全調節性咬合器（ディナー社製 D 5 A）を調節して, 咬合器上に顎運動を再現し, 切歯 路および匊牙路を計測して顆路との比較を行うことにし た。

咬合形式別の顆路傾斜角は，G.F.O. 群では $33.6 \pm$ 5.1度, C.P.O. 群では $34.5 \pm 5.5$ 度であり, 平均值に関 して両者間には有意の差は認められなかった，同様な方 法で顆路傾斜角を検討した呉 $(1987)^{21}$ 'は，著者の結果 よりやや大きいものの，それぞれ $38.5 \pm 6.6 ， 39.8 \pm 5.9$ 度であり, 本研究の結果と同様, 両者間に有意差がない ととを報告している。

また，側方運動時に切曾を含む群の矢状前方顆路傾斜 角は $31.6 \pm 5.9$ 度, 側方運動時に切曾を含まない群では $35.9 \pm 4.0$ 度であった. 平均值の差の検定を行ったとこ 
ろ，両者間には有意の差が認められなかった（表 4)。

顆路は，軟組織である関節円板を介して，下頜頭が滑 走する側頭骨関節窩の前方斜面の形態により特徵づけら れるものであり, 前方決定要素である切蒾路の誘導形態 が顆路には直接的な影響を及ぼさないととが示唆され た。

\section{II. 蒾牙路について}

下䝷運動の様子を直接観察できるのは上下顎蒾牙の接 触状態である，そのため，天然曾および総義歯に付与す べき理想的咬合形式が考案されてきた。との咬合形式は 上下效歯牙の接触状態により特徴づけられるため，前菌 における誘導形態ならびに臼歯の咬合小面の形態は咬合 形式の決定に重要な因子となる。

そこで，歯牙路のうち，まず切歯路について検討し た. 機能的切歯路, 解剖学的切歯路とも, 側方運動に切 歯を含む群と切歯を含まない群の平均值には有意の差が 認められなかったが， G.F.O. 群と C.P.O. 群とは， 後者の平均值が有意に大きいととがわかった。

すなわち，C.P.O.の特徵は，臼雨部は中心咬合位に おいてのみ接触し, 側方運動を行うと即座に離開するこ とである.それに対して G.F.O.は，作業側の全夹牙 により晈合力を分担させるため，側方運動時に作業側歯 牙は前困部から日米部にかけて全ての歯牙が接触するこ とが特徵である.そこで, C.P.O. でディスクルージョ ンを起こさせるためには, 前歯部における誘導角は相対 的に大であることが望ましく，本研究の結果で明らかな ように, C.P.O. が G.F.O. に対して切菌路傾斜角が 有意に大であったのであろう。

下顎第 1 大曰歯における前方咬合小面の矢状面投影傾 斜角は, 切歯路傾斜角の結果之同様の傾向で, 側方運動 に切菌を含む群と含まない群で平均值の差の検定を行っ たところ，両者間には有意の差は認められなかった。 また，G.F.O. 群と C.P.O. 群では，それぞれ 33.2士 $7.7 ， 38.0 \pm 7.3$ 度であり, 平均值に関して C.P.O.の 方が有意に大であることがわかった（表 3 ）.

呉 $(1987)^{21 \prime}$ は，咬合小面を口腔内および咬合器上で 唁查し, 側方運動時に接触している咬合小面を有効咬合 小面, 接触していない咬合小面を非有効咬合小面とし て, 咬合形式別に前方咬合小面傾斜角を测定した。 その 結果, C.P.O. 群は当然すべてが非有効咬合小面であ り，その角度は35.3土10.2度，G.F.O. 群では有効咬合 小面で $29.2 \pm 10.5$ 度, 非有効咬合小面 $28.8 \pm 9.5$ 度であ り, 有効咬合小面, 非有效咬合小面とも C.P.O. の方 が大である傾向であったと報告している．本研究で対象
とした G.F.O.の咬合小面はすべて有効咬合小面を対 象としたもので，與の值よりわずかに大きいもののほほ 同様の傾向にあった。

N 、顆路傾斜角, 切雪路傾斜角, 咬合小面傾斜角の相関

関係について

A . 顆路傾斜角と解剖学的切歯路傾斜角について

顆路と柬牙路との調和は下顎運動には不可欠の要因で あるが，顆路に対する適切な歯牙路に関する報告は少な w.

そこで, 顆路と切曾路の大きさに関して比較を行っ た. その結果，機能的切柬路傾斜角が顆路傾斜角より 大であった例は，G.F.O.，C.P.O. でそれぞれ 62.6 ， $66.7 \%$ で，約 $2 \% 3$ の例で機能的切雬路傾斜角の方が大であ った.また，その相違の平均值は，G.F.O., C.P.O.

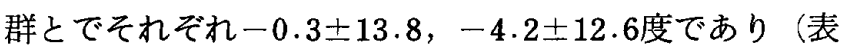
8 ), 両者とも機能的切歯路傾斜角は顆路㑯斜角よりわ ずかに大きく，その差は C.P.O.の方が G.F.O.より 大である傾向にあることがわかった．乙のととは顆路 傾斜角と解剖学的切曾路傾斜角との関係でもほぼ同様で あった. G.F.O. と C.P.O. とでは顆路傾斜角に有意 差がないととは前述したとおりであるが，このように G.F.O. では顆路傾斜角と切曾路傾斜角 との差が 小さ く，C.P.O.では大である傾向があることが明かとなっ た.すなわち，顆路傾斜角と切歯路傾斜角との差が咬合 形式を決定する要因であることが推察された.

機能運動としての下顎前方運動の特徽は, 河野ら（19 $75)^{5)}$ が指摘しているように，切端咬合付近で食物を啮 みきり，下䝷前蒾が上顎前歯舌面を滑走して中心咬合位 へ咬み込む運動である、開口位から食物を啮みきる切端 咬合位までの運動においては，顆頭は下顎が閉口しよう とする方向に回転するが，切端咬合位から中心咬合位へ は切菌路傾斜角之顆路傾斜角との差が回転方向を決定す る要因となる．切柬路傾斜角が顆路傾斜角よりも大きけ れば切端咬合位から中心咬合位への滑走運動時には，顆 頭は閉口時と同じ様な回転運動をするが，切歯路傾斜角 が顆路傾斜角よりも小さい場合には下䫟は閉口している にもかかわらず, 顆頭は開口時に行うべき回転運動をし ており, 本来の開口時の回転方向とは逆方向となってし まう。したがって, 食物を摄取するという一連の下顎運 動に際して, 開口位から閉口し切端咬合位まで咬み込 み, さらに中心咬合位に滑走する際に顆頭の回転方向が 変化するととは, 下顎運動を司る神経筋機構に対して好 ましい状態とはいい難い。

そこで，顆頭が機能運動時に常に同一の運動方向であ 
るととが好ましい，そのためには矢状切歯路傾斜角は矢 状顆路傾斜角より大きいととが望ましく，本研究での結 果のようにほとんごの例で切雨路傾斜角が大きかったも のと思われる。

つぎに，G.F.O. 群と C.P.O. 群の顆路傾斜角と機能 的切蒾路傾斜角の相関係数は，それぞれ $-0.49,-0.30$ であり，両者とも有意の相関関係が認められなかった。 顆路傾 斜角之解剖学的切菌路傾斜角之の関係において む，それぞれー0.57，-0.35であり，ほぼ同様の傾向に あることが確認された（表 $9 ， 10$ ）。さらに，顆路㑯斜 角之切歯路傾斜角との差は， C.P.O. 群の方が G.F.O. 群よりも大きいととから，咬合形式の相違は顆路傾斜角 と切歯路傾斜角との角度の相違がひとつの要因であると とが示唆された。

B . 顆路傾斜角と咬合小面傾斜角との相関関係について 顆路傾斜角之下顎第 1 大田歯の咬合小面傾斜角之を 比較するために，個々の計測値の顆路傾斜角から咬合 小面傾斜角を引いた值を求めたととろ，G.F.O. 群と C.P.O. 群とではそれぞれ $-0.4 \pm 10.6,-3.2 \pm 9.1$ 度 であり，ほとんどの例で咬合小面傾斜角の方が大であっ た (表14). また, G.F.O. 群と C.P.O. 群の相関係数 は，それぞれー0.35，一0.07であり，両者とも有意の相 関関係が認められなかった（表 $9 ， 10$ ）。

顆路傾斜角之機能的切歯路傾斜角および解剖学的切歯 路傾斜角之の比較においては，切歯路傾斜角の方が大で ある傾向であった，咬合小面についても同様に顆路傾斜 角よりも大であり，しかも有意の相関関係が認められな かったととから，下筫運動の前方誘導要素である切歯路 あるいは匊の咬合小面の形態は顆路に影響される可能 性がないととが示唆された。

C . 機能的切菌路傾斜角之咬合小面傾斜角之の相関関係 について

機能的切歯路傾斜角之解剖学的切菌路傾斜角とはほほ 同様の傾向にあったので，機能的切歯路傾斜角を切歯路 の代表とし咬合小面傾斜角との比較を行うことにした.

個々の計測值の機能的切菌路㑯斜角加ら咬合小面傾斜 角を引いた值を求めたとてろ G.F.O. 群と C.P.O. 群

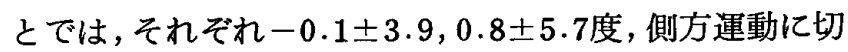
菌を合む群と含まない群とではそれぞれ $0.8 \pm 3.2,0.2$ \pm 5.8 度であり,機能的切菌路傾斜角と咬合小面傾斜角と は，ほとんど差がないととが確認された（表15）。また， G.F.O. 群と C.P.O. 群とで切菌路傾斜角之咬合小面傾 斜角との相関係数を求めたところ，それぞれ $0.95 ， 0.83$ であり，両者に有意の相関関係が認められた $(9,10)$.
G.F.O.は側方運動時に前霜から大田曾にまで接触し ているととが特徽であるため, てのように切歯路傾斜角 と咬合小面傾斜角とに差がなく，しかも有意の相関関 係にあるととは当然考えられることである。しかし， C.P.O.に扔いては側方運動を行うとすぐに菌部が離 開し，接触しないことが特徴であるため，切歯路傾斜角 の方が咬合小面傾斜角よりはるが大であるととが予想 されたにもかかわらず，わずかの差にとどまった．その 理由は, 咬合小面の接触状態は咬合器上あるいは口腔内 で側方限界運動をさせたときの咬合紙の印記部あるいは 視診により判断したものではあるが，見かけ上咬合接触 していても実際にわずかの離開でもあると C.P.O.群あ るいは非有効咬合小面に分類される可能性があるととが 一つの原因として考えられる. また，今回の研究におい ては，咀緭に用いられる運動はほとんど側方限界運動で あるという Lundeen ら (1973) ${ }^{511}$ の報告をもとに，側 方限界運動をさせたときの接触状態から咬合形式を分類 したのであるが，食物を介在したときには必ずしも側方 限界運動のみの運動ではないとと，また介在する食物が 研削材となって咬合小面を形成し，見かけ上は非有効咬 合小面である C.P.O. 群の咬合小面傾斜角が実際の咀嚼 運動時には接触し，切歯路傾斜角とほほ同様の值になっ た可能性があるだめであろう.

\section{結論}

日崡の咬合小面は，上下歯牙の滑走運動によって生じ たものであるため，下顎運動の前方決定要素である前歯 部の誘導形態と, 後方決定要素である顆路とに影響さ れ，両者と調和がとれた形態をしているはずである。し たがって，有茵顎者の咬合関係を追求する場合に，上下

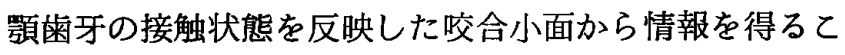
とができれば，簡便で，しかも広範囲の利用が期待でき る.

そこで，個性正常咬合を有する22名の被験者を対象に して，パントグラフ法で描記した運動路をもとに，全調 節性咬合器を調節して得られた顆路, 前曾部の被蓋度, および曰菌部咬合小面の形態的特徵について観察すると ともに, てれらの平均值の相互関係について検討し, 以 下の結論を得た。

1. 咬合形式別に分類すると，G.F.O. 群および C.P.O. 群の割合は，それぞれ45.4，54.6\%であった。

2. 顆路傾斜角は, G.F.O. 群, C.P.O. 群でそれぞ れ33.6 $55.1 ， 34.5 \pm 5.5$ 度であり，平均値に関して両者 間には有意の差は認められなかった。 
3. 機能的切雨路傾斜角は, G.F.O. 群と C.P.O. 群 でそれぞれ $33.4 \pm 10.5 ， 38.7 \pm 10.0$ 度であり，両者間に は有意の差は認められなかった。

4. 解剖学的切霆路傾斜角は, G.F.O. 群と C.P.O. 群でそれぞれ $33.4 \pm 11.1 ， 39.3 \pm 9.8$ 度であり, 両者間 に有意の差が認められた。

5.下顎第 1 大臼崡における前方咬合小面傾斜角は,

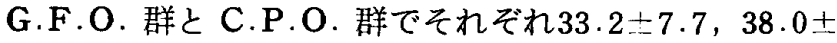
7.3度であり，両者間には有意の差が認められた。

6. 顆路傾斜角と機能的切畨路傾斜角の相関係数は, G.F.O. 群と C.P.O. 群でそれぞれ $-0.49 ，-0.30$ で あり，両者とも有意の相関関係は認められなかった。

7 . 顆路傾斜角之解剖学的切蔝路傾 斜角の相関係数 は，G.F.O. 群と C.P.O. 群でそれぞれ-0.57，-0.35 であり，両者とも有意の相関関係は認められなかった。

8. 顆路傾斜角と咬合小面傾斜角との相関係数は, G.F.O. 群と C.P.O. 群でそれぞれ -0.35，-0.07で
あり，両者とも有意の相関関係は認められなかった。

9 . 機能的切歯路傾斜角と咬合小面傾斜角の相関係数 は，G.F.O. 群と C.P.O. 群でそれぞれ0.95，0.83であ り，両者に有意の相関関係が認められた。

10. G.F.O. 群と C.P.O. 群とを特徴づけるのは顆路 傾斜角と切菌路傾斜角との差であり，差が大きいものが C.P.O.，小さいものがG.F.O. 群になる傾向があっ た。

稿を終わるにあたり，終始御懇篤な御指導と御校閲を 賜った恩師豊田静大教授に対し，深甚なる感謝の意を表 するとともに, 本研究に対し数多くの御援助, 御助言を いただいた三宅茂樹講師に謝意を捧げます。ささらに種々 の御協力をいただきました補緅学教室員諸兄ならびに快 く本研究の被験者を引き受けて下さった諸氏に心より感 謝致します。

\section{引用 文 献}

1) Kurth, L.E. : Balanced occlusion. J. Prosthet. Dent. 4:150-167, 1954.

2 ) Weinberg, L.A. : Diagnosis of facets in occlusal equilibration. J. Amer. Dent. Assoc. $52: 26$ $-35,1956$.

3 ) Cohen, R. : The relationship of anterior guidance to condylar guidance in mandibular movements. J. Prosthet. Dent. 6:758-767, 1956.

4) Huffer, R.A., DeVincenzo, J.P., Cobett, N.E. and Shryock, E.F.: Relationship between the lingual of the maxillary central incisor and the articular eminence in ideal occlusion. Angle Orthod. $42: 44-49,1972$.

5) 河野正司・塩沢育己・中野雅徳：前方滑走運動の菌牙指導要素としての切歯路の研究. 補緅誌 $19: 426$ 一 $433,1975$.

6 ）中野雅徳：側方滑走運動における顆路と歯牙路に関する研究. 補経誌 $19: 647-665 ， 1976$.

7 ）栗山 雷：菊牙誘導要素が平衡側顆路に及ぼす影響について. 補経誌 $23: 126-147,1979$.

8）藤井哲則：正常有囸顎者における咬頭嵌合位とその付近の側方咬合位での咬合様式. 九州歯会誌 $37: 250$ $-264,1983$.

9 ）河野正司：顆路と菌牙路との関係．補緅臨床 $17: 329-338 ， 1984$.

10）久保雅晴：歯牙滑走運動時における顆頭点および切㐘点運動の解析. 九州雨会誌 $38: 83-95,1984$.

11）赤坂䀯道：ヒトの粜の補経学的咬合局面に関する研究. 補綴誌 $9: 1-9,1965$.

12）中尾勝彦：正常天然雨列における咬合小面と歯牙接触に関する研究（咬頭嵌合位）。補経誌 14：1一21， 1970 .

13）早川淑子：臼歯咬合小面に関する研究．補緅誌 $15 ： 350-380 ， 1971$.

14）中尾勝彦：正常天然菌列における咬合小面と歯牙接触に関する研究（後方雨牙接触位，前方滑走運動，側方 滑走運動)。補綴誌 $16: 289-319,1972$.

15）筥塚裕康：函牙滑走運動における接触状態の観察. 㐘科学報 $72 ： 605-646,1972$.

16）内田智幸：歯牙滑走運動時における上下顎四菌部の接触に関する研究。歯科学報 $73: 233$-263，1973. 
17）米沢 徽：滑走運動時における上下頷函牙の接触関係に関する研究. 粜科学報 $77: 1131-1166,1977$.

18）畑 好昭・岩下博美・原田博夫・橋本和男・魚住 哲・川瀬哲子・渡辺文度：有菌額の咬合の統計的観察. 補綴誌 $23: 153-163,1979$.

19）奥田 健：同一個人の20年間における前雬部咬合接触面の推移. 雪科医学 $43: 16-38,1980$.

20）千葉和朗：同一個人の30年間における臼囦部咬合接触面の推移. 蒾科医学 $44: 615-656,1981$.

21）呉 文元：側方限界運動方向における顆路と歯牙路との関係. 九州歯会誌 $41: 384-398,1987$.

22) Stuart, C.E. : Good occlusion for natural teeth. J. Prosthet. Dent. 14:716-724, 1964.

23) Guichet, N.F. : Procedures for occlusal treatment. A treating atlas. Denar Co.,, Calf., 1969.

24) Clayton, J.A., Kotowicz, W.E. and Myers, G.E.: Graphic recordings of mandibular movements : Research criteria. J. Prosthet. Dent. $25: 287-298,1971$.

25）喠見祐三：咬合非誘導と咬合誘導における顆路の変化に関する研究. 歯科学報 $75 ： 1401-1434,1975$.

26）久保田所一：顆路の立体的運動野に関する研究. 九州崡会誌 $29: 307-333 ， 1975$.

27) Winstanley, R.B. : Observations on the use of the Denar pantograph and articulator. $J$. Prosthet. Dent. 38:660-672, 1977.

28) Stansbery, C.J. and Wash, S.: Functional position of checkbite technique. J. Amer. Dent. Assoc. $16: 421-440,1929$.

29）腰原 好：チェックバイト法について。因本蒾科評論 $384: 45$ 一6 1974 .

30）黑田蜀彦：下額運動の咬合器への transfer とくに check-bite 法について． 日本䨑科評論 385：120一 130,1974 .

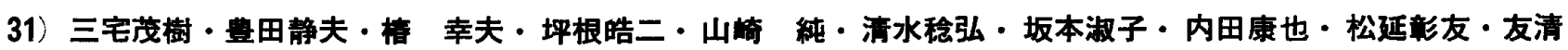
純孝：チェックバイト法により測定した顆路傾斜角について 第 2 報 正常有柬顩者について. 九州柬 会誌 $33: 125-132,1979$.

32）木竜 徽・斎藤義明・野村修一・石岡 靖：下顎運動の診断のための測定および処理システム．医用電子と 生体工学 $18: 27-33,1980$.

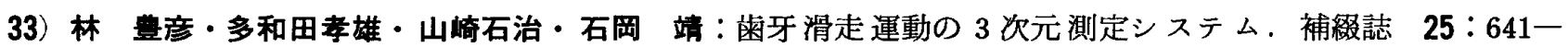
648,1981 .

34）塩澤恭郎：下顎任意点の運動解析 第 2 報 下顎限界運動の立体的解析. 補緅誌 $26: 148-164,1982$.

35) Jankelson, B. : Measurement accuracy of the mandibular kinesiograph. A computerized study. J. Prosthet. Dent. $44: 656-666,1980$.

36）楊 釷榮：種々の体位ならびに咬合記録術式が咬合位に及ぼす影響，九州雨会誌 $37: 265 一 282,1983$ 。

37）和久田一成：タッピング運動を利用した咬合採得法に関する研究. 九州柬会誌 $38: 880$-901，1984.

38）堀 祥二：生理的機能を利用した咬合高径決定法に関する研究. 九州菌会誌 $36: 974-988,1982$.

39）安東俊介：側方運動時における機能的顆路の位置に関する研究. 九州荬会誌 $36: 116-130,1982$.

40）岸本満夫：ヒトの曰歯咬合面形態と補経学的平面との関係について. 九州菊会誌 $29: 598 一 622,1976$.

41）打和貞事：パントグラフの誘導要素が顆路に及ぼす影響. 九州歯会誌 $40: 275-290,1986$.

42）捬水稔弘：総義䨑の珓合小面に関する研究 経日的変化について. 九州米会誌 $41: 623$-636, 1987 .

43) Bonwill, W.G. : The scientific articulation of the human teeth as founded geometrical, mathematical and mechanical laws. Dent. Items. 21:873-880, 1899.

44) Gysi, A. : Die Achsentheorie der Kieferbewegungen und die Facettentheorie der Kauflachenformen der Zahne. Berlin, Handbuch der Zahnheidekunde, Urban \& Schwarzenberg, 1929, 1-171

45）矢崎正方：下筫運動の解剖学的研究. 歯科学報 $34: 791-813,1929$.

46) D'Amico, A. : Functional occlusion of the natural teeth of man. J. Prosthet. Dent. 11:899 $-915,1961$.

47) Alexander, P.C. : Analysis of the cuspid protective occlusion. J. Prosthet. Dent. 13:309- 
$317,1963$.

48) Shore, N.A. : Equilibration of the occlusion of natural dentition. J. Amer. Dent. Assoc. $44: 414-420,1952$.

49) Schuyler, C.H. : An evaluation of incisal guidance and its influence in restorative dentistry. J. Prosthet. Dent. 9:374-378, 1959.

50) Ramfjord, S.P. and Ash, M.M. : Occlusion, W.B. Saunders Co., Philadelphia, $1966,1-396$.

51) Lundeen, H.C. and Wirth, C.G. : Condylar movement patterns engraved in plastic blocks. J. Prosthet. Dent. $30: 866-875,1973$. 